\title{
Pengembangan Alat Peraga Sains Fisika Berbasis Lingkungan untuk Materi Listrik Statis pada Siswa Kelas IX SMP Negeri 3 Pleret
}

\author{
Eliska Preliana \\ Program Studi Pendidikan Fisika FKIP UAD \\ J1. Prof. Dr. Soepomo, SH. Janturan Yogyakarta \\ Surat-e: epreliana@yahoo.com
}

\begin{abstract}
Sampai saat ini pelajaran IPA (fisika) masih dianggap sebagai mata pelajaran yang sulit dan membosankan karena banyak materi yang abstrak. Materi listrik statis pada pokok bahasan teori atom merupakan materi yang abstrak dimana atom dan contoh-contoh pemodelan atom masih dalam bentuk gambar tidak dapat dilihat langsung oleh manusia. Oleh karena itu pemahaman materi listrik statis pada pokok bahasan teori atom perlu diadakan model riil.Untuk itu, peneliti mengembangkan alat peraga sains fisika berbasis lingkungan. Peran peraga salah satunya adalah menjadikan konsep yang abstrak menjadi lebih konkrit.Tujuan dari penelitian ini adalah mengembangkan alat peraga sains fisika berbasis lingkungan yang dapat digunakan sebagai media pembelajaran fisika yang menarik dan bermakna, serta mengetahui kelayakan media pembelajaran tersebut dalam pembelajaran fisika pada materi listrik statis untuk siswa SMP kelas IX.

Subjek penelitian ini adalah siswa di kelas IX SMP Negeri 3 Pleret.Desain penelitian ini menggunakan desain ADDIE (Analysis, Design, Development, Implementation dan Evaluation). Instrumen yang digunakan dalam penelitian ini berupa angket respon untuk ahli materi dan ahli media (dosen dan guru fisika), angket respon untuk siswa dan nilai hasil belajar dari pretest dan posttest. Data yang diperoleh selanjutnya dianalisis secara kuantitatif dan kualitatif.

Berdasarkan analisis penilaian oleh ahli materi dan ahli media, alat peraga sains fisika berbasis lingkungan untuk siswa SMP kelas IX, jika di rata-rata diperoleh hasil $87,50 \%$ yang berada pada kategori sangat layak. Kemudian untuk angket respon siswa terhadap penggunaan alat peraga sains fisika diperoleh rata-rata sebesar 90,92\% yang berada pada kategori sangat layak. Untuk hasil pretest sebelum menggunakan alat peraga diperoleh nilai rata-rata 56,89. Sedangkan dari analisis terhadap hasil posttest setelah menggunakan alat peraga diperoleh rata-rata 85,86 . Berdasarkan hasil analisis tersebut dapat disimpulkan bahwa alat peraga yang dirancang, dibuat dan dikembangkan layak digunakan sebagai alat peraga dalam pembelajaran.
\end{abstract}

Kata kunci: alat peraga, lingkungan, listrik statis.

\section{Pendahuluan}

Dalam dunia pendidikan, fisika merupakan mata pelajaran yang sulit dipahami oleh siswa. Fisika merupakan cabang IPA yang mendasari perkembangan teknologi dan konsep hidup harmonis dengan alam. Sebagai ilmu yang mempelajari fenomena alam, fisika juga memberikan pelajaran yang baik kepada siswa untuk hidup berdasarkan hukum alam. Hukum-hukum fisika merupakan hasil pemikiran manusia yang memiliki keterbatasan, artinya bahwa hukumfisika tidak kebal terhadap perubahan. Berdasarkan perkembangan teknologi konsep hukum alam tidak akan berjalan secara optimal tanpa pemahaman yang baik tentang fisika.

Dalam berbagai proses pembelajaran di Indonesia, peranan guru masih sangat dominan walaupun sebagian dari mereka telah berupaya untuk menjadi fasilitator disamping sebagai sumber informasi. Namun pada kenyataannya pengetahuan manusia sangat terbatas sehingga kita perlu sumber-sumber informasi lainnya baik dalam belajar maupun membelajarkan orang lain.

Guru sebagai penyampai materi pelajaran tidak hanya menyampaikan bahan ajar yang sesuai dengan rancangan program pembelajaran, namun guru juga dituntut untuk bisa memberikan kemudahan bagi para siswa dengan proses 
pembelajaran yang mudah dipahami dan menyenangkan. Siswa diharapkan memperoleh dan menemukan nilai ilmu pengetahuan yang disampaikan guru. Oleh sebab itu pendekatan pembelajaran yang dilakukan oleh guru dalam menyajikan pelajaran perlu diarahkan kepada pemenuhan kebutuhan dan pengharapan siswa dengan menggunakan berbagai sumber informasi. Namun untuk menciptakan suasana pembelajaran seperti itu bukan persoalan yang mudah. Diperlukan komponen-komponen lain untuk mendukung proses pembelajaran agar mudah dan menyenangkan. Salah satu komponen yang bisa memudahkan siswa belajar dengan menggunakan alat peraga.

Peran peraga salah satunya adalah menjadikan konsep yang abstrak menjadi lebih konkrit. Pada pelajaran fisika materi listrik statis merupakan sesuatu yang abstrak dimana atom dan contoh-contoh pemodelan struktur atom tidakdapat dilihat langsung oleh manusia. Oleh karena itu pemahaman materi listrik statis pada pokok bahasan teori atom perlu diadakan upaya pengkongkritan. Salah satunya adalah dengan membuat suatu alat peraga pembelajaran. Dengan alat peraga pembelajaran ini maka materi listrik statis pada pokok bahasan teori atom yang abstrak dapat diamati secara langsung oleh siswa.

Berdasarkan hasil observasi di SMP Negeri 3 Pleret, permasalahan yang ditemukan di sekolah adalah ketidaktersediaan alat peraga untuk pembelajaran fisika pada materi listrik statis. Hal itu menyebabkan kurangnya pemahaman konsep tentang materi yang diajarkan, karena siswa hanya bisa membayangkan sesuatu yang abstrak tanpa melihat secara nyata. Guru sebagai motivator dalam proses pembelajaran dituntut untuk lebih kreatif merancang alat peraga pendidikan yang seefektif dan semurah mungkin. Oleh karena itu diperlukan alat peraga yang mudah didapat namun relevan dengan materi yang dipelajari.

Masalah siswa dalam belajar di kelas salah satunya adalah kurangnya memahami hal-hal penting dari materi yang disajikan dan siswa masih kesulitan menyelesaikan soal hitung menghitung terutama terkait materi listrik statis. Kesulitan itu menyebabkan rendahnya aktivitas siswa mengikuti pembelajaran fisika di kelas dan kurangnya motivasi siswa dalam belajar fisika.

Keterbatasan alat peraga pembelajaran di sekolah dikarenakan mahalnya harga alat peraga dan minimnya dana untuk membeli alat-alat peraga tersebut.

Dalam pembelajaran fisika khususnya untuk materi listrik statis keterbatasan alat peraga ini dapat diatasi dengan pengembangan peraga pembelajaran berbasis lingkungan.

Alat peraga berbasis lingkungan merupakan alat peraga yang terbuat dari bahan-bahan bekas atau barang-barang yang mudah kita temukan di sekitar lingkungan kita [I].
Selama ini pembelajaran fisika materi listrik statis baru sebatas pemaparan contoh, siswa belum pernah melihat langsung contoh-contoh pemodelan struktur atom. Dengan alat peraga ini pemahaman siswa dalam belajar sains fisika, khususnya dalam materi listrik statis akan lebih baik.

Pelaksanaan pembelajaran fisika yang aktif dan kreatif dapat diwujudkan dalam perancangan alat peraga sains fisika sehingga siswa termotivasi dalam belajar fisika. Oleh karena itu peneliti merasa perlu untuk melakukan penelitian dengan tema "Pengembangan Alat Peraga Sains Fisika Berbasis Lingkungan untuk Materi Listrik Statis pada Siswa Kelas IX SMP Negeri 3 Pleret dengan harapan bahwa alat peraga sains fisika mampu menjembatani guru dalam menjelaskan konsep fisika terutama materi listrik statis.

Berdasarkan latar belakang yang telah dikemukakan diatas, dapat diidentifikasi masalah sebagai berikut :

I. Materi Listrik Statis dianggap sebagai mata pelajaran yang sulit dipahami oleh siswa.

2. Kurangnya pemahaman siswa tentang konsep struktur atom pada materi listrik statis.

3. Siswa masih kesulitan menyelesaikan soal hitung menghitung terutama terkait materi listrik statis.

4. Ketidaktersediaan alat peraga sains fisika terutama pada materi listrik statis.

5. Rendahnya aktivitas siswa mengikuti pembelajaran fisika di kelas dan kurangnya motivasi siswa dalam belajar fisika.

Penelitian ini bertujuan untuk:

I. Untuk mengembangkan alat peraga sains fisika untuk pembelajaran Listrik Statis.

2. Untuk mengetahui kelayakan alat peraga dengan pembelajaran fisika pada materi listrik statis di SMP Negeri 3 Pleret.

\section{Kajian Pustaka}

Penelitian yang dilakukan oleh Nur Ika Dewi Sartika Fitriani,[2] yang berjudul "Pengembangan Alat Peraga Sains Fisika dengan Memanfaatkan Sampah Anorganik Materi Kelistrikan dan Kemagnetan pada Siswa SMP/MTs", menyimpulkan bahwa alat peraga sains fisika yang dikembangkan layak untuk diaplikasikan di sekolah SMP/MTs. Produk yang dibuat terdiri dari generator Van de Graff, gaya Lorentz, dan motor listrik.

Cikanawati,[3] yang berjudul "Pengembangan Alat Peraga IPA dari Pengolahan Limbah Kertas untuk Pembelajaran Listrik Statis", menyimpulkan bahwa melalui pengembangan didapatkan produk baru yang berbentuk tiga dimensi. Produk baru yang dihasilkan terbuat dari 
pengolahan sampah dan limbah bangunan yaitu berupa pemodelan atom yang berbentuk 3 dimensi.

Agus Slamet Isnanto, $[\mathrm{I}]$ yang berjudul "Pengaruh Penggunaan Alat Peraga Berbasis Lingkungan (APBL) pada Materi Dinamika Partikel terhadap Kemampuan Psikomotor PI Peserta Didik Kelas X SMA Negeri I Kutowinangun", menyimpulkan bahwa hasil analisis menunjukkan terdapat pengaruh yang signifikan antara alat peraga berbasis lingkungan (APBL) terhadap psikomotor PI peserta didik.

Menurut AECT (Association of Education and Community Technology) dalam Azhar Arsyad[4] adalah segala sesuatu yang digunakan orang untuk menyalurkan pesan. Dengan demikian media merupakan alat yang digunakan untuk menyampaikan atau mengantarkan pesanpesan pengajaran.

Alat Peraga adalah alat bantu untuk mendidik atau mengajar supaya apa yang diajarkan mudah dimengerti anak didik[5]. Dari pengertian diatas dapat disimpulkan bahwa alat peraga yaitu suatu piranti atau alat bantu yang digunakan oleh guru untuk mendidik dan menyampaikan materi pelajaran baik berupa benda atau perilaku sehingga memudahkan siswa untuk memahaminya. Alat peraga dapat digunakan sebagai media pembelajaran serta menyalurkan pesan yang dapat merangsang pikiran, perasaan, dan kemauan siswa sehingga dapat mendorong terjadinya proses belajar pada diri siswa.

Menurut Soelarko[6] alat peraga adalah tiap-tiap benda yang dapat menjelaskan suatu ide, prinsip, gejala atau hukum alam. Soelarko juga menjelaskan bahwa fungsi alat peraga adalah memvisualisasikan sesuatu yang tidak dapat dilihat atau sukar dilihat hingga nampak jelas dan dapat menimbulkan pengertian atau meningkatkan persepsi seseorang.

Kesimpulannya bahwa alat peraga berbasis lingkungan adalah alat peraga yang terbuat dari alat dan bahan dari barang-barang bekas atau yang sederhana, murah, dan mudah didapatkan di lingkungan sekitar yang dapat dijadikan peraga pembelajaran

\section{Metode Penelitian/Eksperimen}

Menurut Sugiyono[7] metode penelitian dan pengembangan atau dalam bahasa inggrisnya Research and Development adalah metode penelitian yang digunakan untuk menghasilkan produk tertentu, dan menguji keefektifan produk tersebut. Penelitian ini bertujuan untuk menciptakan produk baru yang berupa alat peraga untuk siswa SMP kelas IX. Penelitian ini diklasifikasikan dalam
Penelitian dan Pengembangan atau Research and Development (R \& D).

Dalam penelitian ini, prosedur yang digunakan mengacu pada desain pengembangan model ADDIE (Analysis, Design, Development, Implementation, Evaluation). Pemilihanmodel pengembangan ini didasarkan pada alasan bahwa tahapan-tahapan dasar desain pengembangan ADDIE sederhana, mudah dipelajari, simpel serta lebih mudah dipraktikan dalam pengembangan media pembelajaran.

Kelima fase atau tahap dalam model ADDIE dilakukan secara sistematis. Model desain sistem pembelajaran ADDIE dengan komponen-komponennya dapat dijelaskan sebagai berikut ini.

I. Analysis (tahap analisis)

Salah satu masalah dalam dunia pendidikan yang masih terjadi saat ini yaitu terbatasnya media pembelajaran yang dapat membangun pengetahuan peserta didik. Berdasarkan pengamatan di SMP Negeri 3 Pleret, dalam pembelajaran peserta didik belum menggunakan alat peraga sains fisika untuk materi listrik statis pada pokok bahasan teori atom. Peserta didik hanya menggunakan buku paket pelajaran yang diberikan oleh guru.

\section{Design (tahap perencanaan)}

Pada tahap ini, kegiatan yang dilakukan oleh peneliti adalah merancang suatu media ajar berupa alat peraga sains fisika. Rancangan disusun dengan melakukan tahap awal yaitu pengumpulan referensi mengenai materi listrik statis pada pokok bahasan atom yang bertujuan agar mendapatkan banyak sumber yang akurat untuk membuat alat peraga sains fisika.

Tahap selanjutnya adalah membuat desain tentang beberapa pemodelan struktur atom yang akan dibuat sebagai alat peraga dan apa saja yang akan ditulis dalam buku pedoman penggunaan alat peraga sains fisika dan bagaimana urutan langkah penyajian materinya serta langkah-langkah penggunaan alat peraga tersebut. Produk ini diharapkan dapat meningkatkan produktivitas pembelajaran fisika di SMP Negeri 3 Pleret.

\section{Development (tahap pengembangan)}

Setelah diperoleh rancangan alat peraga sains fisika, kemudian dilanjutkan dengan tahap pengembangan alat peraga meliputi tahap pembuatan atau penyusunan alat peraga sesuai dengan hasil perancangan yang diperoleh tersebut. Data kelayakan alat peraga sains fisika diperoleh dengan cara memberikan angket kepada ahli materi dan ahli media (dosen dan guru fisika). Angket tersebut berupa lembar penilain yang terdiri dari aspek isi buku, penyajian, kemanfaatan, dan pengoperasian dengan tujuan pembuatan 
alat peraga yang selanjutnya akan direvisi sesuai dengan masukan dari para ahli.

\section{Implementation (tahap implementasi)}

Dalam tahap ini, setelah produk melalui proses pengembangan dan revisi dari para ahli maka alat peraga sains fisika siap untuk diimplementasikan kepada siswa kelas IX SMP Negeri 3 Pleret. Setelah menggunakan alat peraga sains fisika tersebut, siswa diminta untuk mengisi angket respon, kemudian siswa juga diminta untuk memberi tanggapan atau saran terhadap alat peraga tersebut.

\section{Evaluation (tahap evaluasi)}

Evaluasi adalah proses untuk melihat apakah media pembelajaran yang dikembangkan telah berhasil dan layak digunakan sebagai media pembelajaran atau tidak[8]. Pada tahap ini dilakukan proses untuk menganalisis hasil implementasi sebagai bahan perbaikan alat peraga. Masukan dari siswa kemudian dianalisis dan dilakukan revisi kembali pada bagian-bagian alat peraga sains fisika yang belum sesuai.Setelah produk direvisi, maka produk akhir yang dihasilkan berupa alat peraga sains fisika pada materi listrik statis untuk siswa kelas IX SMP Negeri 3 Pleret telah teruji validasinya dan dapat dikatakan layak sebagai media pembelajaran.

Uji coba produk dilakukan terhadap para ahli, yaitu: ahli materi, ahli media dan pengguna yaitu siswa.

Data yang digunakan dalam penelitian pengembangan ini adalah:

a. Data Kualitatif

Data kualititatif berupa masukan, koreksi, dan kritik yang diberikan oleh dosen ahli materi, dosen ahli media, dan guru fisika terhadap alat peraga sains fisika.

b. Data Kuantitatif

Data kuantitatif adalah data hasil penilaian yang diperoleh dari lembar penilaian atau angket oleh ahli materi dan ahli media, angket respon siswa dan hasil belajar fisika siswa yang berupa pretest dan posttest.

Instrumen penelitian adalah alat yang digunakan peneliti untuk memperoleh data. Instrumen yang digunakan dalam penelitian ini adalah:

a. Lembar Penilaian Produk

Lembar Penilaian untuk dosen ahli materi, dosen ahli media dan guru fisika digunakan untuk menilai kualitas alat peraga sains fisika yang telah dikembangkan berdasarkan aspek isi buku, penyajian,

\section{b. Angket Respon Siswa}

Angket respon siswa digunakan untuk mengetahui bagaimana tanggapan siswa terhadap alat peraga dan kelayakan alat peraga.Dalam angket respon ini terdapat 3 aspek penilaian alat peraga sains fisika, yaitu kriteria pembelajaran, kriteria tampilan dan kriteria teknis.

c. Interview (wawancara)

Pedoman wawancara berisi daftar pertanyaan yang bertujuan untuk mengungkap informasi tentang metode pembelajaran yang biasa dilakukan oleh guru, kelayakan penyajian alat serta untuk mendapat saran dan masukan terkait alat peraga yang telah dikembangkan.Pedoman wawancara guru dapat dilihat di lampiran I.7.

\section{d. Tes hasil belajar fisika siswa (pretest dan posttest)}

Tes hasil belajar fisika digunakan untuk mengukur pemahaman siswa terhadap kompetensi yang diajarkan.Uji kompetensi berupa soal pilihan ganda sebanyak I0 butir dan essay 5 butir dalam waktu I x 30 menit.Soal pilihan ganda memuat empat pilihan jawaban.Jika jawaban benar diberi skor I sedangkan jika jawaban salah diberi skor 0 . Untuk soal essay jika jawaban benar diberi skor 2 sedangkan jika jawaban salah diberi skor 0 .

\section{Pretest}

Pretest digunakan untuk mengetahui kemampuan awal siswa sebelum alat peraga di ujicobakan. Soal pretest dapat dilihat pada lampiran I.5.

\section{Posttest}

Posttest digunakan untuk mengetahui kemampuan akhir siswa setelah alat peraga di ujicobakan.Soal posttest dapat dilihat pada lampiran I.5.

\section{e. Rencana pelaksanaan pembelajaran (RPP)}

Rencana kegiatan peneliti yang berisi skenario pembelajaran tahap demi tahap mengenai aktivitas yang dilakukan siswa bersama peneliti.

Teknik analisis data sebagai berikut:

a. Data Kualitatif

Data kualitatif diperoleh dari hasil penilaian ahli materi, ahli media, dan pengguna yang berupa masukan, tanggapan, kritik, saran dan perbaikan yang berkaitan dengan alat peraga sains fisika yang dikembangkan. Tanggapan atau saran dari validator yang dianggap tepat untuk pengembangan alat peraga sains fisika maka akan digunakan sebagai bahan perbaikan pada tahap revisi alat peraga sains fisika.

b. Data Kuantitatif

Hasil penilaian oleh ahli materi, ahli media, dan angket respon siswa berupa data kuantitatif. Data tersebut kemudian dianalisis menggunakan pedoman pengkorvesian nilai. Nilai akumulasi ini merupakan jumlah nilai total dari 
setiap komponen penilaian. Data analisis menggunakan presentasi keberhasilan sebagai berikut [9]

$$
N P=\frac{R}{S M} \times 100 \%
$$

dimana:

$$
\begin{aligned}
& N P=\begin{array}{l}
\text { nilai persen skor tiap aspek penilaian alat peraga } \\
\text { sains fisika yang diharapkan (dicari) }
\end{array} \\
& R=\begin{array}{l}
\text { jumlah skor dari tiap aspek penilaian alat peraga } \\
\text { sains fisika }
\end{array} \\
& \begin{array}{c}
S M=\begin{array}{l}
\text { skor maksimal tiap aspek penilaian alat peraga } \\
\text { sains fisika }
\end{array}
\end{array}
\end{aligned}
$$

Dari persentase yang diperoleh kemudian ditransfer kedalam bentuk nilai, dan dikonversikan dalam bentuk tabel pedoman penilaian.

\section{Hasil Penelitian dan Pembahasan}

\section{Analisis data dari ahli materi dan ahli media}

Setelah alat peraga sains fisika dinyatakan layak oleh dosen pembimbing, selanjutnya dilakukan proses penilaian oleh dua ahli materi dan ahli media. Hasil analisis penilaian instrumen oleh ahli materi dan ahli media terhadap alat peraga fisika dapat digambarkan seperti dalam diagram dibawah ini.

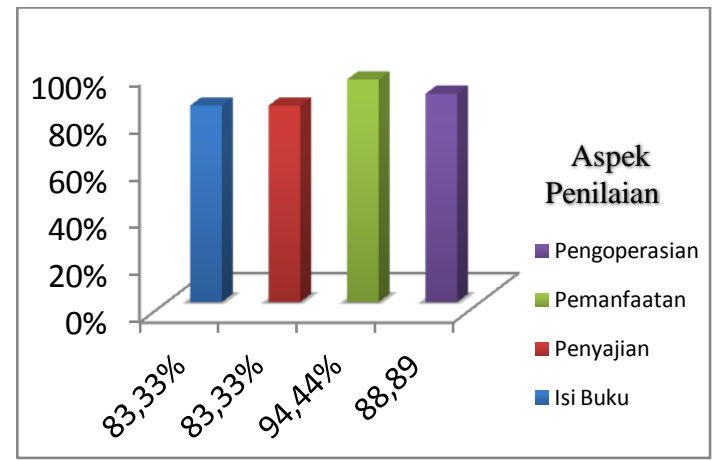

Gambar I. Hasil analisis penilaian instrumen oleh ahli materi dan ahli media

\section{Hasil Analisis Data Pretest dan Posttest}

Setelah alat peraga sains fisika dinyatakan layak oleh ahli materi, ahli media dan guru fisika, maka alat peraga sains fisika siap diimplementasikan kepada siswa SMP.Uji coba alat peraga sains fisika dilaksanakan di SMP Negeri 3 Pleret kelas IX A dengan melibatkan 29 siswa. Proses uji coba dilaksanakan pada tanggal II September 2014.

Dari data analisis terhadap hasil pretest, disimpulkan bahwa 29 siswa kelas IX A sebelum menggunakan alat peraga sains fisika memperoleh nilai rata-rata 56,89. Hal ini menunjukkan bahwa pemahaman siswa pada saat pretest berada dalam kategori cukup baik. Dari data analisis terhadap hasil posttest, disimpulkan bahwa 29 siswa kelas IX A setelah menggunakan alat peraga memperoleh nilai rata-rata 85,86 .

Dengan berpedoman pada konversi nilai, nilai rata-rata tersebut masuk dalam kategori baik dan terdapat perbedaan yang sangat signifikan pada hasil belajar siswa. Berdasarkan hasil analisis pretest dan posttest tersebut dapat disimpulkan bahwa pemahaman siswa dalam kegiatan pembelajaran menggunakan alat peraga lebih baik dan signifikan dalam meningkatkan hasil belajar.

\section{Hasil Analisis Angket Respon Siswa}

Setelah pelaksanaan uji coba selesai, siswa sebagai subjek uji coba diminta untuk mengisi angket respon siswa terhadap alat peraga sains fisika yang mereka gunakan dalam pembelajaran.Bila hasil angket respon siswa tersebut disajikan dalam bentuk diagram hasilnya dapat dilihat dibawah ini.

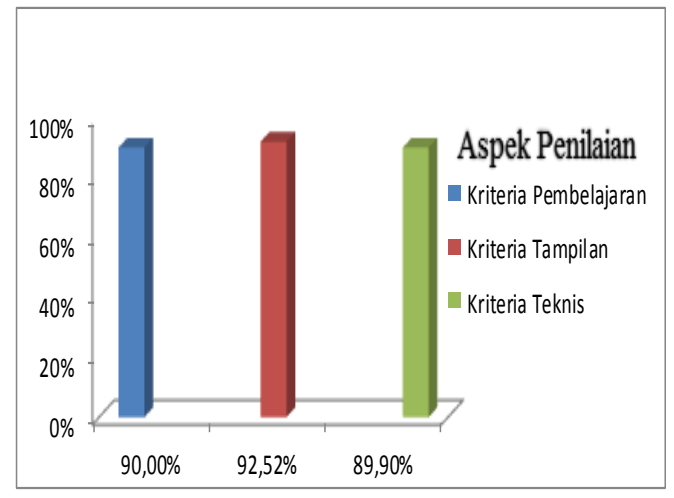

Gambar 2. Hasil angket respon siswa

\section{Kesimpulan}

Berdasarkan hasil penelitian dan pembahasan diperoleh kesimpulan sebagai berikut:

I. Telah dikembangkan alat peraga sains fisika yang dapat dijadikan sebagai media pembelajaran fisika yang menarik dan bermakna pada materi listrik statis pokok bahasan teori atom untuk siswa SMP kelas IX.

2. Alat peraga sains fisika dinyatakan layak digunakan sebagai media pembelajaran yang menarik dan bermakna pada materi listrik statis pokok bahasan teori atom untuk siswa SMP kelas IX. Berdasarkan angket respon pada kriteria pembelajaran diperoleh $90 \%$, kriteria tampilan diperoleh $92,52 \%$, kriteria teknis diperoleh $89,90 \%$. 


\section{Kepustakaan}

[I] Slamet, Agus. dkk. 2013. Pengaruh Penggunaan Alat Peraga Berbasis Lingkungan (APBL) pada Materi Dinamika Partikel terhadap Kemampuan Psikomotor. PI Peserta Didik Kelas X SMA Negeri I Kutowinangun. Jurnal Inkuiri. Vol. 4. No. I, 2013: 30-33

[2] Fitriani, Sartika Dewi. 2013. "Pengembangan Alat Peraga Sains Fisika dengan Memanfaatkan Sampah Anorganik Materi Kelistrikan dan Kemagnetan pada Siswa SMP/MTs".Skripsi. Yogyakarta: UIN Sunan Kalijaga

[3] Cikanawati, 20I I. "Pengembangan Alat Peraga IPA dari Pengolahan Limbah Kertas untuk Pembelajaran Listrik Statis". JP2F. Vol.2 No.2, 201 I:I55-I64

[4] Arsyad Azhar. 2002. Media Pembelajaran. Jakarta: PT. Raja Grafindo Persada.

[5] Depdikbud.2007. Kamus Besar Bahasa Indonesia. Jakarta: Balai Pustaka

[6] Soelarko. 1980. Audio Visual: Media komunikasi ilmiah pendidikan penerangan. Bandung: Binacipta

[7] Sugiyono. 2014.MetodePenelitianPendidikan: Pendekatan Kuantitatif, Kualitatif, dan R\&D. Bandung: Alfabeta.

[8] Pribadi, Benny A. 2009. Model Desain Sistem Pembelajaran. Jakarta: Dian Rakyat.

[9] Purwanto, M. Ngalim. 2006. Prinsip-prinsip dan Teknik Evalusi Pengajaran. Bandung: PT Remaja Rosdakarya 